\title{
RANCANG BANGUN SISTEM INFORMASI DONOR DARAH BERBASIS WEB (STUDI KASUS : UNIT KEGIATAN MAHASISWA KORPS SUKARELA UNIVERSITAS MULAWARMAN)
}

\author{
Muzi Burrakhman'1), Indah Fitri Astuti²), Dyna Marisa Khairina ${ }^{3)}$
}

\author{
1,2,3) Jurusan Ilmu Komputer, FMIPA, Universitas Mulawarman \\ Jalan Barong Tongkok No. 4 Kampus Gunung Kelua Samarinda, Kalimantan Timur \\ Email : muzi@bsmsite.com ${ }^{1)}$, indahfitriastuti@fmipa.unmul.ac.id ${ }^{2}$, dyna.ilkom@gmail.com ${ }^{3)}$
}

\begin{abstract}
ABSTRAK
Masyarakat yang membutuhkan darah sering mengalarni kesulitan ketika mencari informasi persediaan darah. Hal ini dikarenakan Palang Merah Indonesia (PMI) atau Unit Transfusi Darah (UTD) belum mempunyai pangkalan data pedonor yang dapat diakses dengan cepat. Perlu ditemukan cara memecahkan permasalahan yang ada dengan menyediakan sebuah program sistem informasi layanan donor darah yang dapat di akses oleh masyarakat. Sistem Informasi Donor Darah berbasis WEB merupakan sebuah cara untuk menampilkan halaman web Sistem informasi donor darah secara online sehingga diharapkan masyarakat yang membutuhkan informasi donor darah dapat mengakses informasi yang di buat. Pemrograman PHP dan database MySQL dengan dukungan framework CodeIgniter dapat mempermudah sitem informasi donor darah berbasis web diharapkan dapat digunakan untuk mengetahui para pendonor darah yang ada Universitas Mulawarman yang di kelola oleh Unit Kegiatan Mahasiswa Universitas Mulawarman berkerja sama dengan Unit Transfusi Darah Cabang Palang Merah Indonesia (UTDC PMI) Cabang Samarinda.
\end{abstract}

Kata Kunci : sistem informasi, donor darah, web

\section{PENDAHULUAN}

Darah merupakan salah satu komponen sistem transport yang sangat vital keberadaannya. Fungsi vital darah di dalam tubuh antara lain sebagai pengangkut zat-zat kimia seperti hormon, pengangkut zat buangan hasil metabolisme tubuh, dan pengangkut oksigen dan karbondioksida. Selain itu, komponen darah seperti trombosit dan plasma darah memiliki peran penting sebagai pertahanan pertama dari serangan penyakit yang masuk ke dalam tubuh. Transfusi darah adalah suatu tindakan medis yang bertujuan mengganti kehilangan darah pasien akibat kecelakaan, operasi pembedahan atau oleh karena suatu penyakit. Darah yang tersimpan di dalam kantong darah dimasukan ke dalam tubuh melalui selang infus.

Sehubungan dengan adanya program kerja Unit Kerja Mahasiswa Korps Sukarela Universitas Mulawarman selanjutnya dalam penulisan disingkat menjadi UKM KSR UNMUL berkerja sama dengan Unit Transfusi Darah Cabang Palang Merah Indonesia (selanjutnya dalam penulisan disingkat menjadi UTDC PMI Samarinda untuk membantu program pemerintah dalam memenuhi kebutuhan darah di Kalimantan Timur khususnya wilayah Samarinda yang sudah berjalan selama 2 tahun dibutuhkan sebuah sistem informasi donor darah yang berguna sebagai database untuk memudahkan mencari pendonor darah agar bisa membantu orang yang membutuhkan transfusi darah sehingga dapat menyelamatkan nyawa seseorang yang membutuhkan darah tersebut.

Dengan adanya Sistem Informasi Donor Darah berbasis web akan memudahkan masyarakat yang membutuhkan transfusi darah khususnya di daerah Kalimantan Timur Samarinda sehingga kekurangan stok darah dari UTDC PMI Samarinda dapat teratasi dan sekaligus membantu program pemerintah dalam mengatasi kekurangan stok darah. Diharapkan sistem informasi donor darah berbasis web ini dapat mempermudah mencari datadata pendonor darah yang diperlukan dengan cepat saat ada yang membutuhkan transfusi darah atau pun ada jadwal rutin donor darah yang di jalankan oleh UKM KSR UNMUL berkerja sama dengan UTDC PMI Samarinda setiap satu minggu sekali satu Fakultas di wilayah belajar Kampus Universitas Mulawarman Samarinda.

\section{TINJAUAN PUSTAKA \\ Sistem Informasi}

Sistem adalah kumpulan dari elemen-elemen yang berintreraksi untuk mencapai suatu tujuan tertentu (Jogiyanto, 2005). Menurut Jerry Fitzchald, Ardra F. FitzGerald, dan werren D. Stallings, Jr., suatu sistem adalah suatu jaringan kerja dari prosedur-prosedur yang saling berhubungan, berkumpul bersama-sama untuk melakukan suatu kegiatan atau utnuk menyelesaikan sesuatu sasaran yang tertentu (Jogiyanto, 2005). Informasi adalah data yang diolah menjadi bentuk yang lebih berguna dan lebih berarti bagi yang menerimanya. Sumber dari informasi adalah data. Data merupakan bentuk jamak dari bentuk tunggal datum atau data item. Data adalah kenyataan yang menggambarkan suatu kejadian-kejadian dan kesatuan nyata. Kejadia-kejadian (events) adalah sesuatu yang terjadi pada saat tertentu. Data 
merupakan bentuk yang masih mentah yang belum dapat bercerita banyak, sehingga perlu diolah lebih lanjut (Jogiyanto, 2005).

Informasi juga dapat menggambarkan kejadian nyata yang digunakan untuk pengambilan keputusan. Sumber dari informasi adalah data yang berbentuk huruf, simbol, alfabet, dan sebagainya. Menurut Robert A.Leitch/K.Roscoe Davis, sistem informasi adalah suatu sistem di dalam suatu organisasi yang mempertemukan kebutuhan pengolahan transaksi harian, mendukung operasi, bersifat manajerial kegiatan strategi dari suatu organisasi dan menyediakan pihak luar tertentu dengn laporan-laporan yang diperlukan (Jogiyanto, 2005).

\section{Framework CodeIgniter}

Framework dalam sistem berorientasi objek, merupakan kumpulan class yang melambangkan bentuk abstrak untuk pemecahan sejumlah masalah yang berhubungan (Howe, 1995). Framework adalah kumpulan perintah atau fungsi dasar yang membentuk aturan-aturan tertentu dan saling berintraksi satu sama lain sehingga dalam pembuatan aplikasi web kita harus mengetahui atauran dari framework tersebut. Dengan framework (dalam hal ini framework PHP), kita tidak perlu memikirkan kode perintah/fungsi dasar dari aplikasi web kita (Wardana, 2010). Sebuah framework selain menyediakan lingkungan pengembangan sendiri juga menyediakan berbagai macam fungsi siap pakai yang bisa kita gunakan dalam pembuatan sebuah aplikasi berbasis web.

CodeIgniter adalah framework aplikasi web yang open source untuk bahasa pemrograman PHP. CodeIgniter memiliki banyak fitur yang membuatnya berbeda dengan framework lainnya. Tidak seperti beberapa framework PHP lainnya, dokumentasi untuk framework ini sangat lengkap,yang mencakup seluruh aspek dalam framework. CodeIgniter juga mampu bekerja pada lingkungan shared hosting karena memiliki ukuran yang sangat kecil, namun memiliki kinerja yang sangat luar biasa (Griffiths, 2010). CodeIgniter dikembangkan oleh Rick Ellis, dengan versi awal yang dirilis pada 28 Februari 2006. Dari tahun itulah hingga sekarang, telah muncul versi CodeIgniter yang terus berkembang dengan penambahan fitur baru dari versi sebelumnya. Untuk versi terbaru dari CodeIgniter adalah versi 2.1.4. Bagaimana suatu proses data mengalir pada sistem yang menggunakan CodeIgniter Framework dapat diilustrasikan pada gambar 2.1:

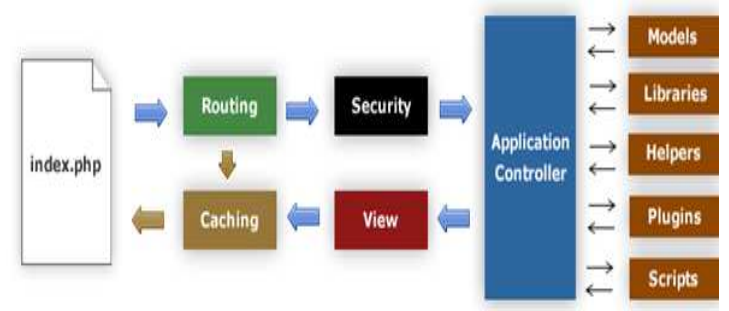

Gambar 2.1. Proses Data Mengalir Pada Sistem (Sumber : Basuki, 2010)
Keterangan Gambar 2.1 :

1. Index.php berfungsi sebagai Front controller, menginisialisasi untuk menjalankan CodeIgniter.

2. Routing memeriksa HTTP request untuk menentukan apa yang harus dilakukan dengannya.

3. Jika Caching aktif, maka hasilnya akan langsung dikirimkan ke browser dengan mengabaikan aliran data normal.

4. Security, Sebelum controller dimuat, HTTP request dan data yang dikirimkan user akan difilter untuk keamanan.

5. Controller memuat model, libraries, plugins, helpers, dan semua yang diperlukan untuk memproses permintaan.

6. Akhirnya View yang dihasilkan akan dikirimkan ke browser. Jika Caching aktif, maka view akan disimpan sebagai caching dahulu, sehingga pada permintaan berikutnya langsung ditampilkan.

\section{Model View Controller (MVC)}

Model-View-Controller (MVC) pertama kali diperkenalkan peneliti Xerox PARC yang bekerja pada bahasa pemrograman Smalltalk di akhir tahun 1970-an dan pada awal 1980-an. Smalltalk adalah bahasa pemrograman yang berorintasi objek, bertipe dinamis, dan reflektif. Smalltalk pertama kali digunakan dalam pembelajaran edukasi, dan hal ini berbeda dari data mainframe dan struktur kontrol dalam program Smalltalk yang terlibat pada Windowed User Interfaces, konsep pemrograman berorintasi objek, pengantar pesan antara komponen-komponen objek, dan kemampuan untuk memonitor dan memodifikasi struktur dan perilakunya sendiri (Griffiths, 2010). Singkatnya. Model-View-Controller (MVC), adalah pola desain pengembangan perangkat lunak. MVC adalah sebuah pendekatan untuk memisahkan aplikasi menjadi tiga segmen, yaitu Models, Views, dan Controller.

MVC menstrukturisasi aplikasi dengan cara tersebut untuk mempromosikan penggunaan dari kode program di ilustrasikan pada Gambar 2.2.

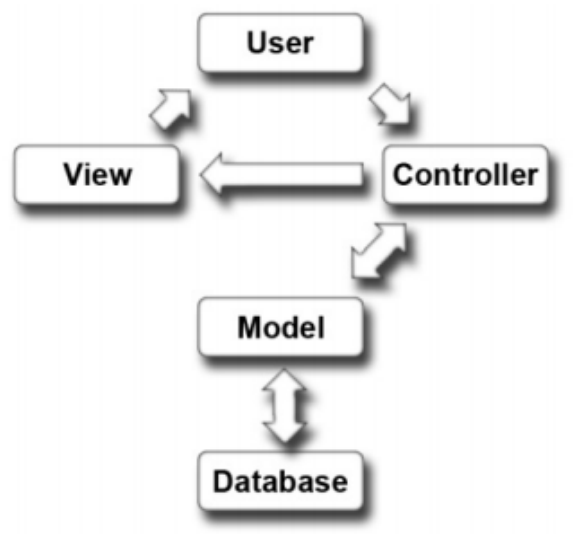

Gambar 2.2. Ilustrasi MVC

(Sumber : Griffiths, 2010) 
Berdasarkan gambar 2.2 dapat di ketahui bahwa ketika datang sebuah permintaan dari user, maka permintaan tersebut akan ditangani oleh Controller, kemudian Controller akan memanggil Model jika memang diperlukan oprasi database. Hasil query oleh Model kemudian akan dikembalikan ke controller. Selanjutnya Controller akan memanggil View yang tepat dan menkombinasikannya dengan hasil query Model. Hasil akhir dari oprasi ini akan ditampikan ke browser yang selanjutnya bisa dilihat oleh user.

\section{PHP}

PHP adalah bahasa scripting untuk sisi server yang dirancang secara khusus untuk web. Dalam halaman HTML dapat dimasukan kode-kode PHP yang akan dijalanklan setiap kali halaman tersebut dieksekusi, kode-kode PHP akan diinterpretasikan pada server web dan menghasilkan HTML atau Output lainnya yang akan dilihat oleh pengunjung web ( Welling \&Thompson, 2003). PHP disusun tahun 1994 dan merupakan hasil kerja keras seseorang, rasmus Lerdorf. Kemudian dilanjutkan oleh orang lain dan terlah melewati tiga kali penyusunan ulang secara besar untuk memberikan hasil produk yang matang seperti yang ada sekarang ini. Pada januari 2001, PHP digunakan hampir lima juta daerah diseluruh dunia, dan jumlah ini terus bertambah (Welling \&Thompson, 2003). PHP merupakan produk Open Source. PHP awalnya berarti Personal Home Page, tetapi diubah dengan penamaan konvensi rekursif GNU dan sekarang PHP ialah Hypertext Preprocessor (Welling \&Thompson, 2003).

\section{MySQL}

MySQL adalah sistem manajemen database yang besifat open source. MySQL adalah pasangan serasi dari PHP. MySQL dibuat dan dikembangakan oleh MySQL AB yang berada di Swedia (Basuki, 2010). MySQL merupakan sistem manajemen database yang besifat rasional. Artinya data-data dikelola dalam database akan diletakan pada beberapa tabel yang terpisah sehingga memanipulasi data akan menjadi cepat (Basuki, 2010). MySQL dapat digunakan untuk mengelola data base mulai dari yang terkecil samapai dengan yang terbesar. MySQL juga dapat manjalankan perintah-perintah Structured Query Language (SQL) untuk mengelola database-database rasional yang ada didalamnya (Basuki, 2010).

\section{XAMPP Server}

XAMPP Server adalah perangkat lunak gratis yang mendukung banyak sistem operasi, merupakan kompilasi dari beberapa program untuk menjalankan fungsinya sebagai server yang berdiri sendiri, yang terdiri atas program Apache HTTP Server, MySQL database, dan penerjemah bahasa yang dirulis dengan PHP dan Perl. XAMPP adalah nama yang merupakan singkatan dari $\mathrm{X}$ berbagai sistem oprasi (Linux, MAC, Windows), Apache,
MySQL, PHP, PERL.Program ini tersedia dalam GNU General Public License dan bebas, merupakan web server yang mudah digunakan yang mampu melayani halaman dinamis (Griffiths, 2010).

\section{UML (Unified Modelling Language)}

Menurut Fowler (2004), UML (Unified Modeling Language) adalah keluarga notasi grafis yang didukung oleh meta-model tunggal, yang membantu pendeskripsian dan desain sistem perangkat lunak, khususnya sistem yang dibangun menggunakan pemrograman berorientasi objek (OOP). UML membuat dan membentuk model, tetapi tidak dapat menyampaikan kapan dan apa model yang seharusnya dibuat. UML bukan hanya bahasa visual saja, namun juga dapat secara langsung dihubungkan ke berbagai bahasa pemrograman, seperti JAVA, C++, Visual Basic atau bahkan dihubungkan secara langsung kedalam OODB. Proses pendokumentasian UML meliputi: requirement, arsitektur, design, source code, project plan, test dan prototype.

Pemodelan dengan UML terdiri dari banyak tipe diagram yang berbeda untuk memodelkan sistem perangkat lunak, masing-masing diagram UML didesain untuk menunjukkan satu sisi dari bermacam-macam sudut pandang (perspektif) dan terdiri dari tingkat abstraksi yang berbeda, diantaranya yaitu: Use case, Class, Object, State, Activity, Sequence, Collaboration, Component dan Deployment Diagram.

\section{HASIL DAN PEMBAHASAN DESKRIPSI SISTEM}

Aplikasi sistem ini dibangun menggunakan bahasa pemrograman PHP (Hypertext Preprocessor) dengan Framework CodeIgniter dan MySql yang berfungsi sebagai media penyimpanan data, yang terdiri dari beberapa tabel yang saling berhubungan. Tabel-tabel yang digunakan adalah tabel dlmbg_admin_operator, dlmbg_operator_donor, dlmbg_operator_artikel. Gambaran aplikasi sistem informasi donor darah berbasis web dapat dilihat pada bab selanjutnya yang menjelaskan secara detail sistem informasi ini.

\section{PERANCANGAN SISTEM}

\section{Use Case Diagram Pengelolaan File}

Use Case Diagram menggambarkan apa saja aktifitas yang dilakukan oleh suatu sistem dari sudut pandang pengamatan luar. Dalam sistem informasi ini admin adalah pengelola sistem yang memiliki hak akses penuh terhadap semua fungsifungsi yang ada di aplikasi sistem informasi ini yang dapat ditunjukan seperti pada gambar 4.1 


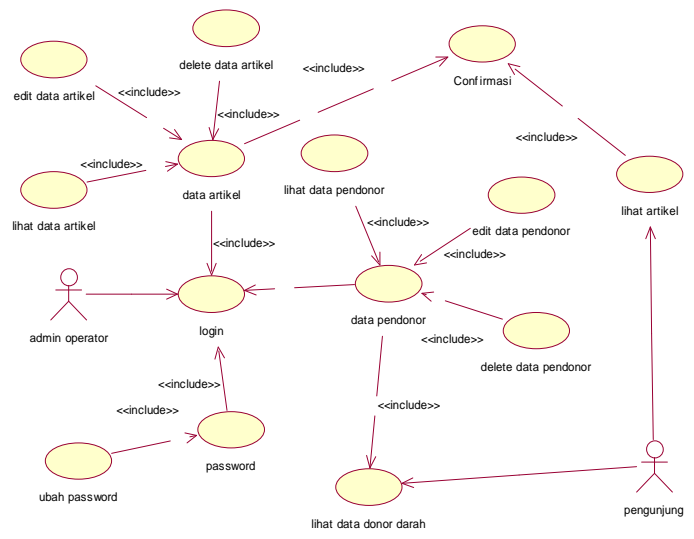

Gambar 4.1 Use Case Diagram Pengolahan Data

\section{Sequence Diagram}

Setelah melakukan login, user dapat melakukan aktifitas menambahkan data pada class data pendonor, artikel, password dan setelah itu data disimpan. Alur sequence diagram seminar Admin Operator dapat dilihat pada gambar 4.2

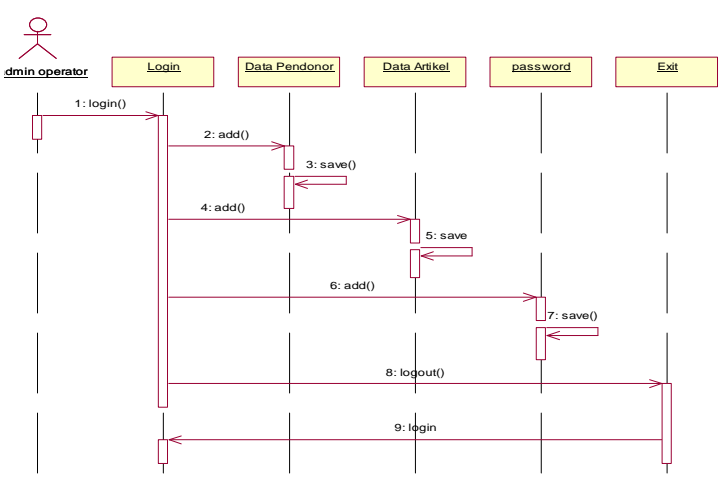

Gambar 4.2 Sequence Diagram Admin Operator

\section{Class Diagram Pengelolaan File}

Pada sistem pengelolaan aplikasi sistem informasi donor darah ini terdapat 3 buah class, dimana seluruh class saling terkait diantaranya adalah class dlmbg_admin_operator, class dlmbg_operator_artikel, class dlmbg_operator_donor dilihat pada gambar 4.3
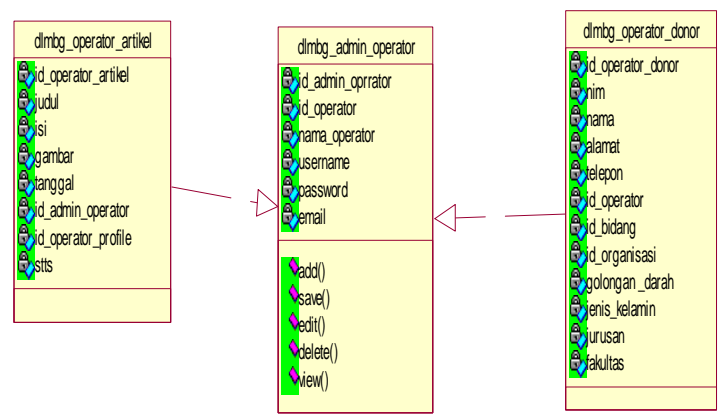

Gambar. 4.3 Class Diagram Pengolahan Data

\section{Activity Diagram Admin Operator}

Pada pengguna aplikasi terlihat aktifitas login dan sistem akan memproses login tersebut jika berhasil maka akan menampilkan data pendonor, dan data artikel sehingga pengguna dapat menginputkan data. Alur activity diagram Admin Operator dapat dilihat pada gambar 4.4

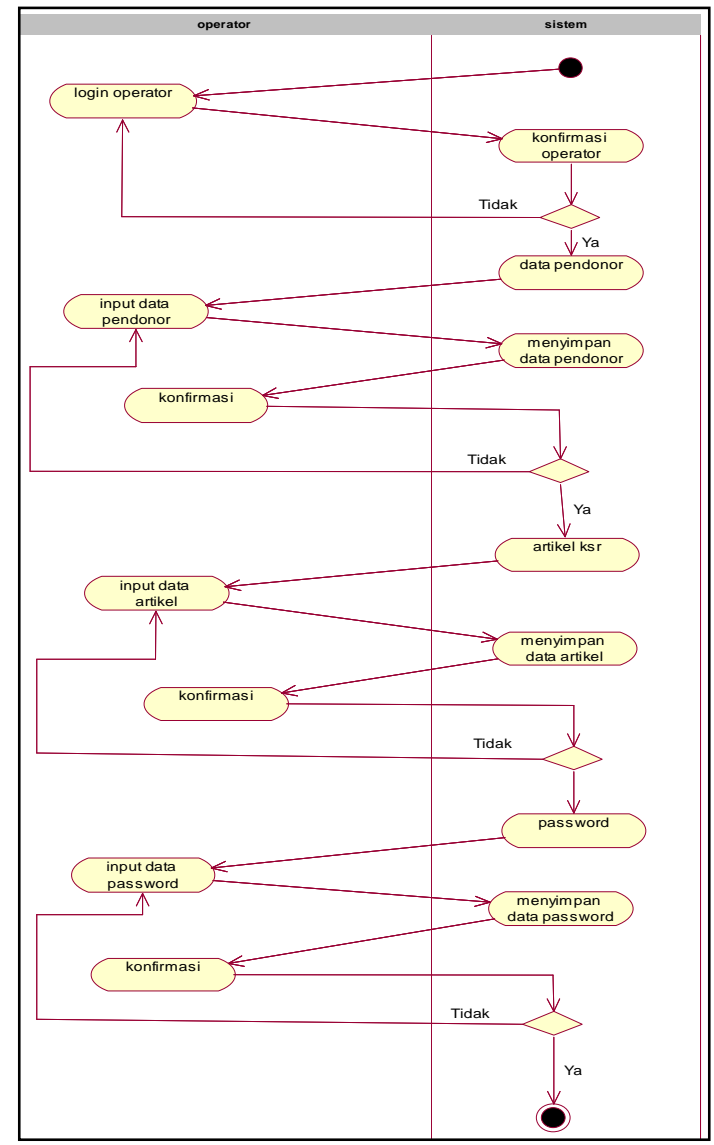

Gambar. 4.4 Activity Diagram Admin Operator

\section{IMPLEMENTASI SISTEM}

Implementasi sistem merupakan tahap yang dilakukan sebelum aplikasi disampaikan pada keadaan sebenarnya. Hal ini berguna agar aplikasi yang dibangun dapat sesuai dengan tujuan.

\section{Form Menu Utama}

Form menu utama merupakan form home. Pada form menu utama ini hanya memiliki tampilan yang berisi berbagai halaman informasi yang menampilkan untuk header ada menu profil,sambutan komandan, anggota KSR, struktur anggota data anggota KSR, data pendonor dan galeri untuk menu header bawah ada menu beranda, berita, pengumuman,agenda list download, dan buku tamu untuk tampilan body ada slide berita, sambutan Komandan KSR UNMUL, menu login, poto komandan KSR UNMUL, angkatan, link terkait, index berita, jajak pendapat, pengumuman terbaru, agenda ksr unmul, statistik pengunjung, dan untuk menu footer terdapat galeri kegiatan dan 
artikel KSR UNMUL.Tampilan form menu utama dapat dilihat pada gambar 4.10

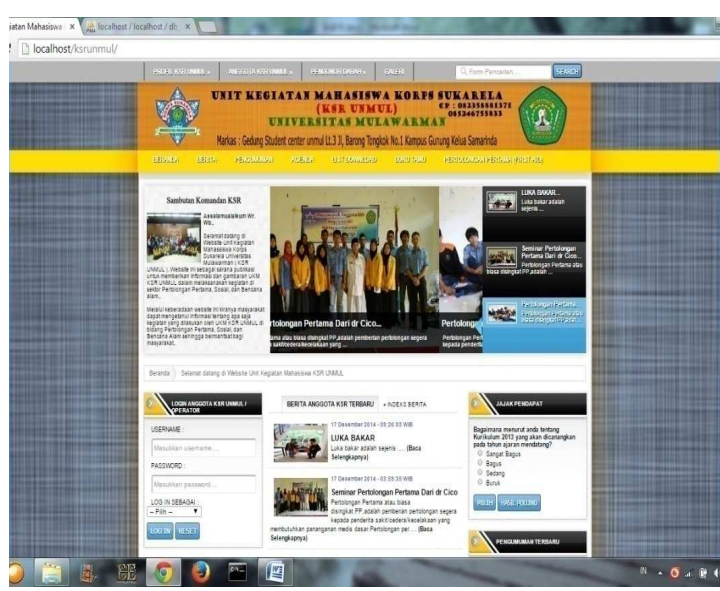

Gambar 4.10. Form Menu Utama

\section{Form Login}

Form login digunakan untuk mengakses menu yang ada pada form menu utama. Untuk dapat mengakes sistem diminta untuk menginputkan username dan password. Form login memiliki 3 jenis pilihan hak akses antara lain hak akses anggota, hak akses operator dan hak akses superadmin. Tampilan form menu login dapat dilihat pada gambar 4.1

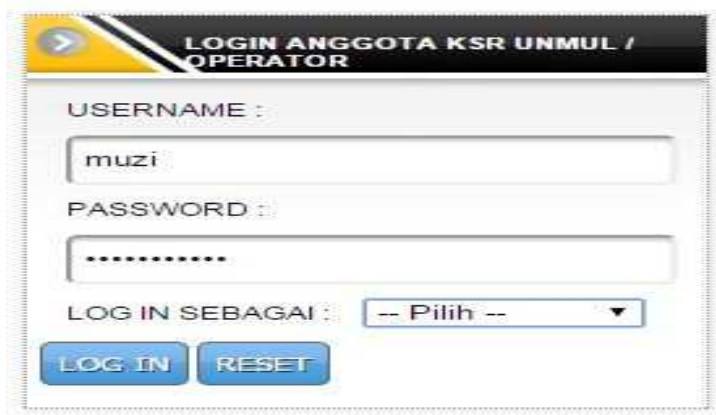

Gambar 4.11 Form Login

\section{Form Tampilan Data Pendonor}

Form tampilan data pendonor ini berisi datadata pendonor yang di dapat dari kegiatan donor darah yang dilakukan di Universitas Mulawarman setiap satu minggu sekali per fakultas, form ini menampilkan data yang meliputi NIM, Nama Pendonor,Golongan Darah, Jenis Kelamin, Frekuensi Donor, Terakhir Donor, Fakultas, Jurusan, pengunjung bisa melihat dengan langsung data-data pendonor terkecuali alamat dan nomor telepon yang bisa dilihat oleh admin operator yang bertugas sebagai admin penginput data donor darah melalui akun operator sehingga ketikan ada yang membutuhkan pendonor darah bisa menghubungi admin KSR UNMUL untuk mendapatkan informasi lebih lanjut atau mengisi menu buku tamu untuk bertanya dengan admin. Tampilan form data pendonor dapat dilihat pada gambar 4.12

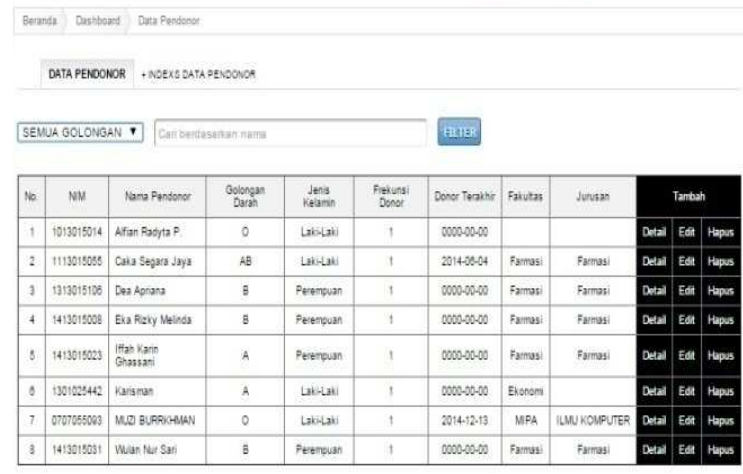

Gambar 4.12 Form Tampilan Data Pendonor Operator

\section{Form Data Pendonor Operator}

Form data pendonor ini bisa di akses melalui login dengan hak akses operator yang di seting untuk menginputkan data pendonor, didalam menu ini terdapat beberapa pilihan tambah, ubah, hapus dan detail yang terdapat pada gambar 4.13

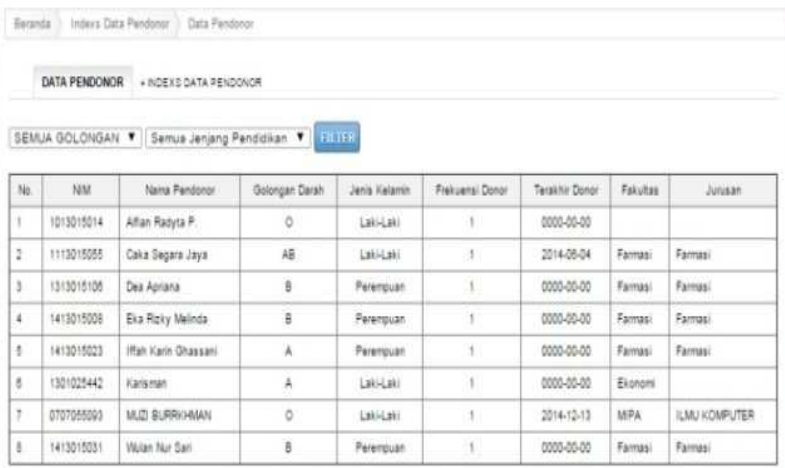

Gambar 4.13 Form Tampilan Data Pendonor

\section{Form Tambah Data Pendonor Operator}

Form tambah data pendonor operator ini berfungsi untuk menambah data pendonor baru. Tampilan form tambah data pendonor operator dapat dilihat pada gambar 4.14

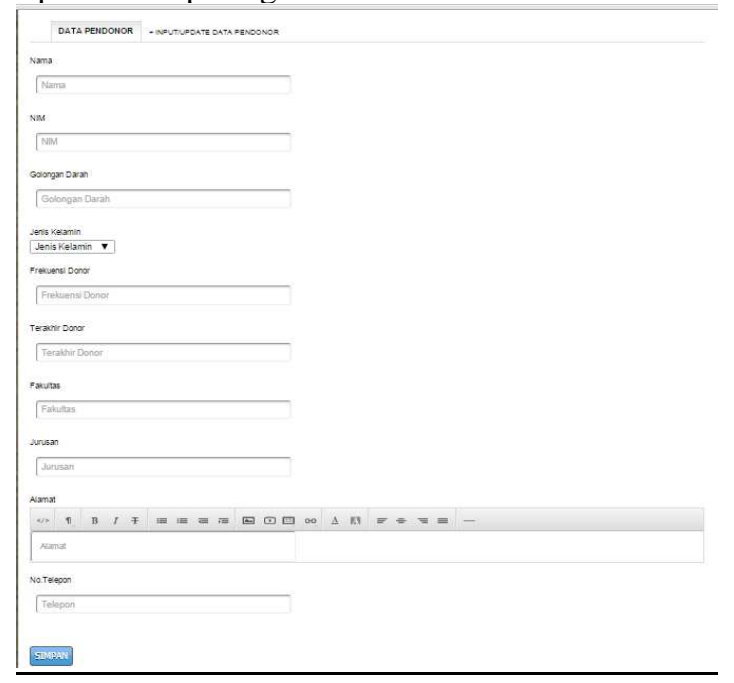

Gambar 4.14 Form Tambah Data Pendonor Operator 


\section{Form Edit Data Pendonor Operator}

Form ubah data pendonor operator ini berfungsi untuk mengubah data yang sudah ada atau menambahkan data yang kurang. Tampilan form ubah data pendonor operator dapat dilihat pada gambar 4.15.

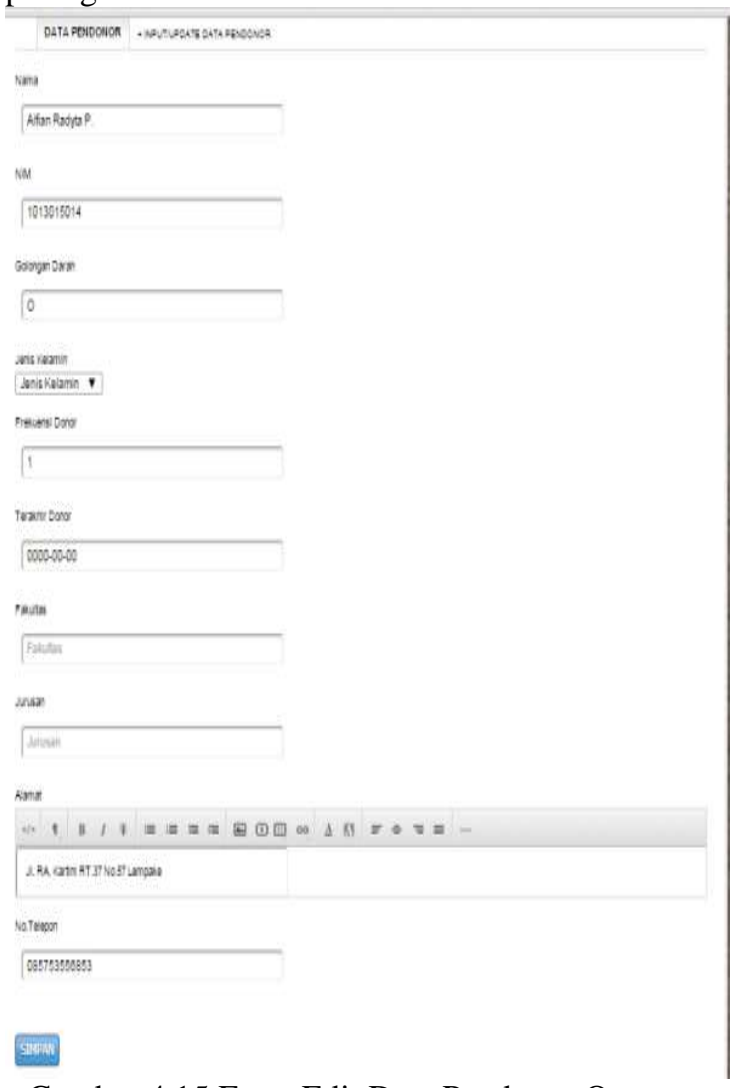

Gambar 4.15 Form Edit Data Pendonor Operator

\section{Form Detail Data Pendonor Operator}

Form detail data pendonor operator ini berfungsi untuk melihat data secara keseluruhan karena data yang d tampilkan pada tabel tidak mencantumkan alamat dan nomor telepon $d$ karenakan privasi data pendonor. Tampilan form detail data pendonor operator dapat dilihat pada gambar 4.16

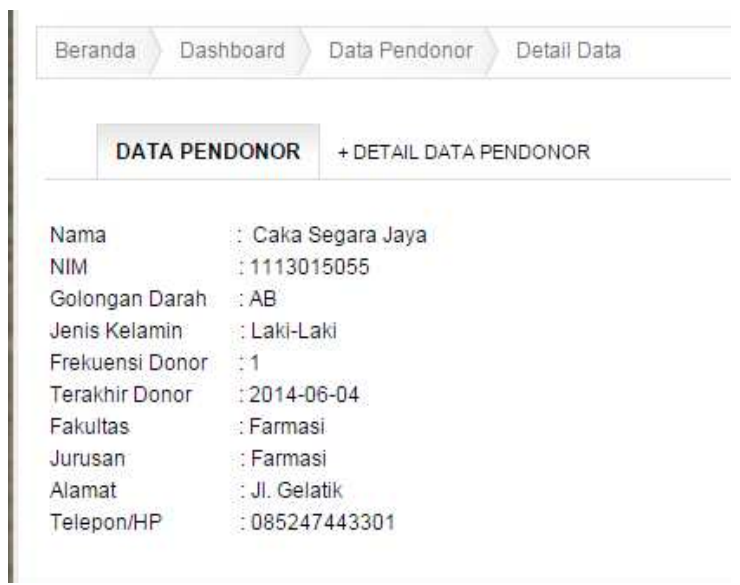

Gambar 4.16 Form Detail Data Pendonor Operator

\section{Form Hapus Data Pendonor Operator}

Form hapus data pendonor operator ini berfungsi untuk menghapus data pendonor jika terjadi kesalahan dalam penginputan data pendonor dengan cara mengklik tombol hapus pada data yang ingin di hapus. Tampilan form hapus data pendonor operator dapat dilihat pada gambar 4.17

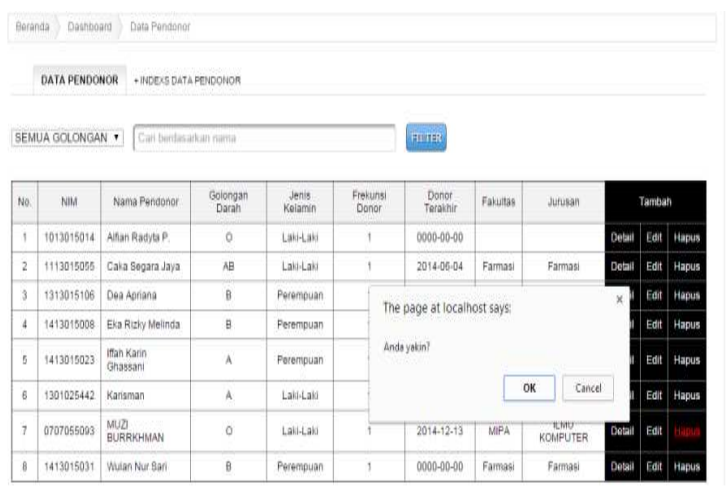

Gambar 4.17 Form Hapus Data Pendonor Operator

\section{Form Pencarian Data Pendonor}

Form pencarian data pendonor sama seperti form tampilan data pendonor pengunjung bisa memanfaatkan fasilitas pencarian data pendonor agar bisa mendapatkan data pencarian yang diinginkan sesuai dengan keinginan pengunjung misalkan pengujung ingin mencari data pendonor yang bergolongan darah $\mathrm{AB}$ maka cukup dengan memilih pilihan golongan darah $\mathrm{AB}$ maka data yang di tampilkan pada tabel akan menampikan data pendonor yang bergolongan darah $\mathrm{AB}$ dan seperti itu seterusnya. Tampilan form pencarian data pendonor dapat dilihat pada gambar 4.18

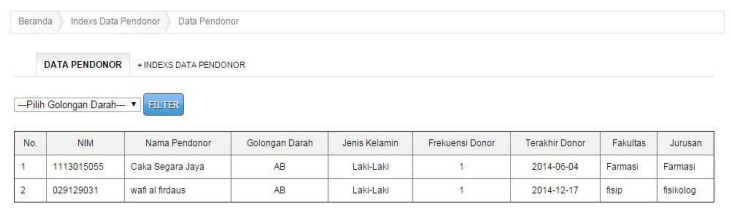

Gambar 4.18 Form Pencarian Data Pendonor

\section{Form Artikel Operator}

Form artikel operator adalah tambahan menu untuk admin operator disini admin bisa menambahkan beberapa artikel akan tetapi harus memalui persetujuan dari super admin atau admin tertinggi, super admin memiliki hak akses full terhadap semua konten yang ada di form sistem informasi donor darah ini dan menyeleksi semua postingan apakah bisa bedampak buruk pada sistem informasi ini. Tampilan form artikel operator dapat dilihat pada gambar 4.19

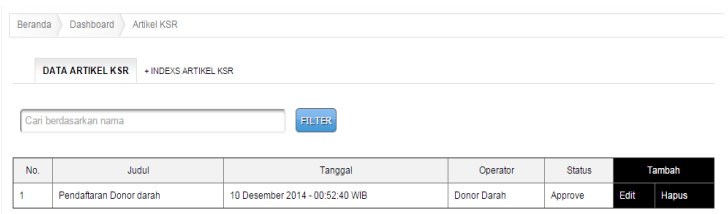

Gambar 4.19 Form Artikel Operator 


\section{Form Password Operator}

Form password operator berfungsi untuk mengubah password. Tampilan form pasword operator dapat dilihat pada gambar 4.20

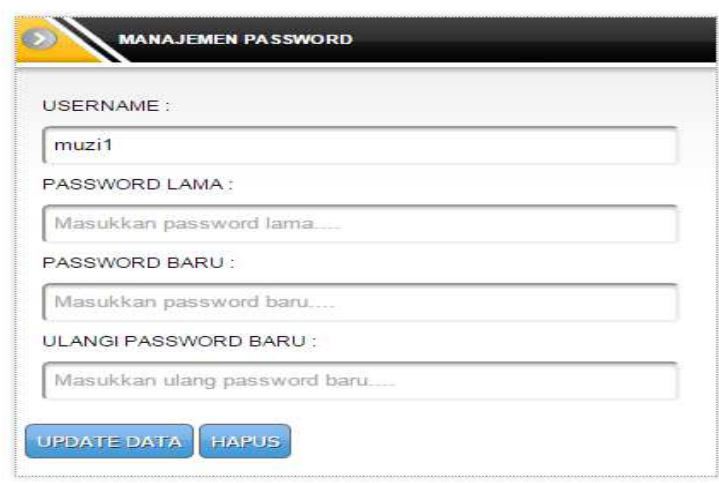

Gambar 4.20 Form Password

\section{PENGUJIAN SISTEM}

Uji Coba Implementasi

Uji coba implementasi dilakukan dari tahap awal penginputan hingga hasil akhir tahap akhir untuk mengetahui apakah aplikasi yang dibangun dari hasil penelitian yang telah dilaksanakan dapat beroprasi dengan tujuan yang diharapkan.

\section{Login}

Tahap awal pengoprasian aplikasi sistem informasi ini adalah login, dimana user menginputkan username dan password yang valid memlilih logian sebagai operator seperti yang terdapat pada gambar 4.21

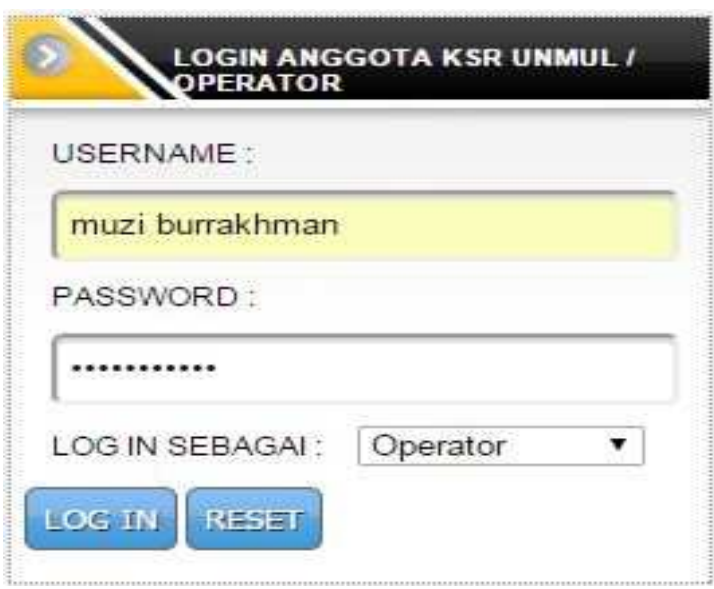

Gambar 4.21. Tahap Login Operator

\section{Menu Dashboard}

Tahapan berikutnya adalah menu dashboard dimana menu ini akan tampil apabila login berhasil atau valid, pada menu dashboard ada pilihan beberapa menu diantara adalah menu pilihan data pendonor, artikel KSR, password dan log out seperti yang terdapat pada gambar 4.22

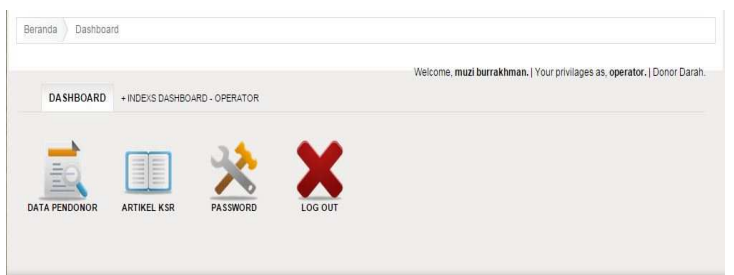

Gambar 4.22 Tahap Menu Dasboard

\section{Menu Donor Darah}

Pada tahapan ini terdapat form donor darah dimana data pendonor dapat dilihat oleh operator dan bisa ditambahkan data baru, diedit, hapus dan meliat dengan detail data masing-masing pendonor seperti yang terdapat pada gambar 4.23

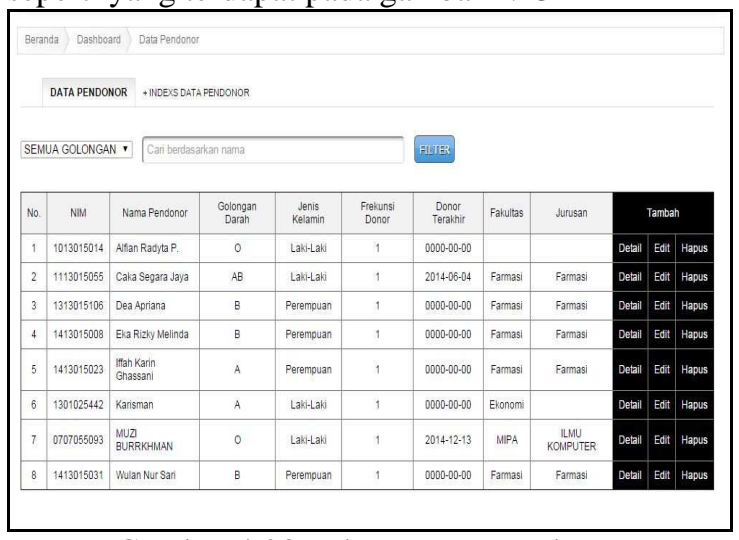

Gambar 4.23 Tahap Menu Pendonor

\section{Tambah Data Pendonor}

Pada tahapan ini untuk menambahkan data pendonor operator harus menekan pilihan tambah kemudian akan muncul form input data pendonor yang berisi Nama, NIM, Golongan Darah, Jenis Kelamin, Frequensi Donor , Terakhir Donor, Fakultas, Jurusan, Alamat dan No telepon seperti yang terdapat pada gambar 4.24

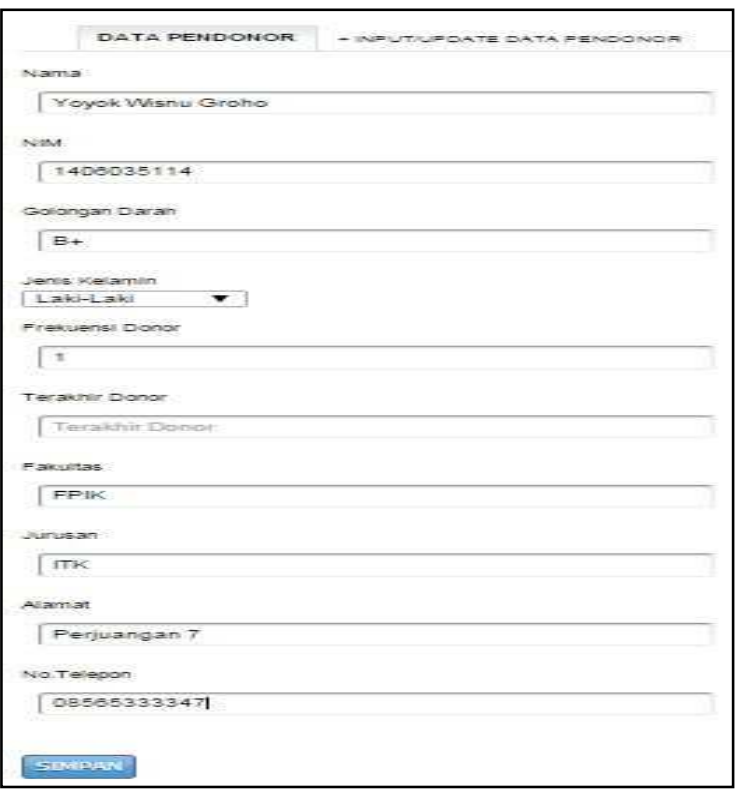

Gambar 4.24 Tahap Tambah Data Pendonor 


\section{Edit Data Pendonor}

Pada tahapan ini operator dapat mengubah data pendonor jika terjadi update data atau terjadi kesalahan saat penambahan data seperti yang terdapat pada gambar 4.25

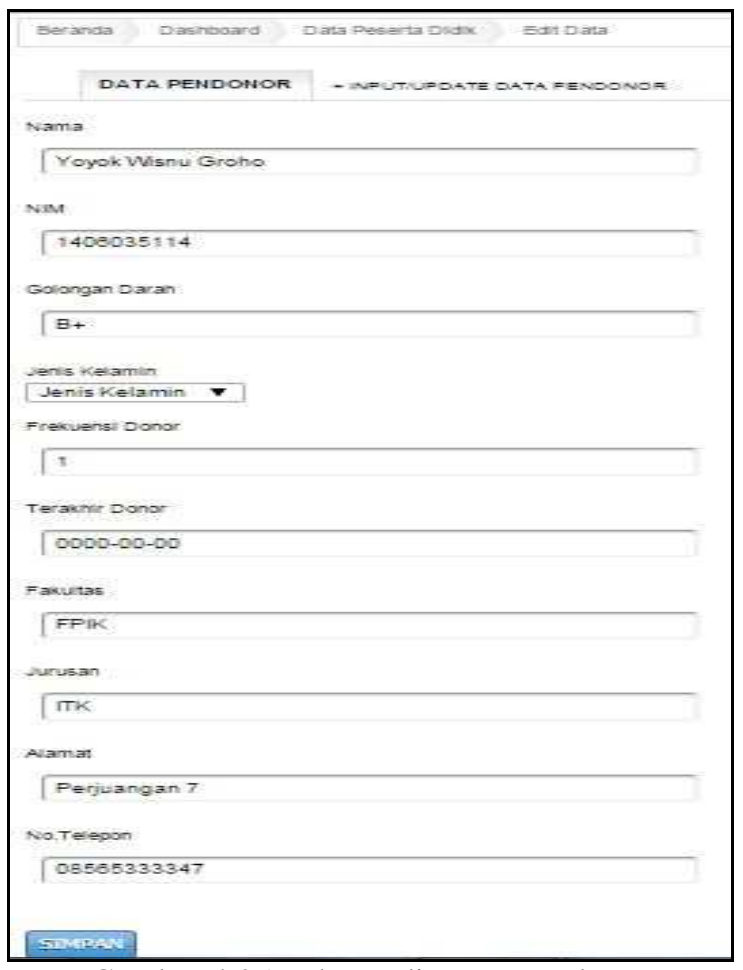

Gambar 4.25 Tahap Edit Data Pendonor

\section{Detail Data Pendonor}

Pada tahapan ini data pendonor dapat dilihat secara lengkap dengan menekan pilihan detail pada masing-masing data pendonor fungsi dari detail adalah menampilkan data secara keseluruhan karena ada 2 variabel yang tidak ditampilkan pada tampilan tabel operator dan tabel umum yang bisa dilihat user tanpa harus login,, karena 2 bariabel tersebut bersifat privasi dua variabel tersebut adalah alamat dan no telepon seperti yang terdapat pada gambar 4.26

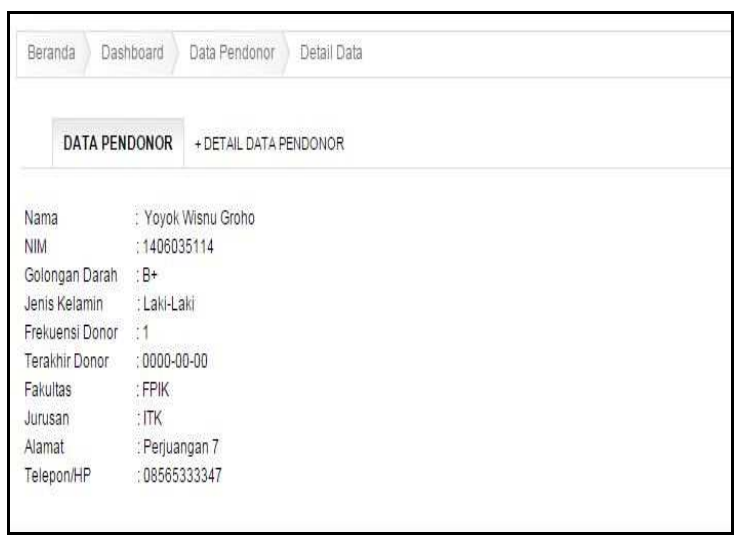

Gambar 4.26 Tahap Edit Data Pendonor

\section{Hapus Data Pendonor}

Pada tahapan ini data bisa langsung di hapus pada pilihan hapus disetiap data donor sehinga tidak perlu memakai form hapus dan akan muncul pesan "anda yakin?" seperti yang terdapat pada gambar 4.27

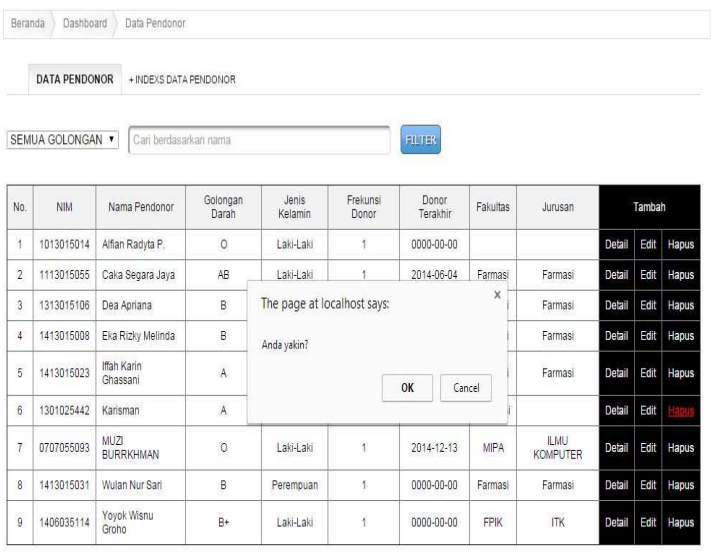

Gambar 4.27 Hapus Data Pendonor

\section{Tampilan Data Pendonor Untuk Umum}

Pada tahapan ini berguna untuk publikasi data pendonor darah ke pengunjung tanpa harus login sehingga mempermudah dan mempercepat dalam pencarian data pendonor para pengunjung tinggal memilih menu Pendonor Darah dan memilih sub menu data pendonor seperti yang terdapat pada gambar 4.28.

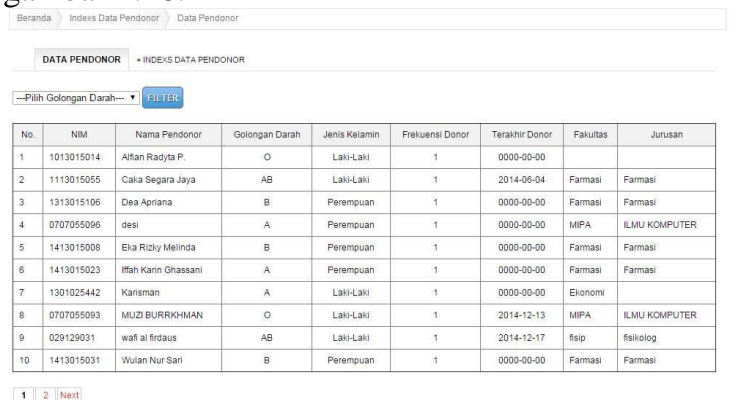

Gambar 4.28 Tampilan Data Pendonor

\section{KESIMPULAN}

Berdasarkan hasil pembahasan yang telah dijabarkan pada bab sebelumnya, maka didapat beberapa kesimpulan dibawah ini:

1. Dengan adanya sistem informasi donor darah ini dapat mempermudah dan mempercepat dalam proses pencarian data pendonor dan langung menghubungi call center unit kegiatan mahasiswa KSR Unversitas Mulawarman

2. Penyampaian informasi donor darah kepada masyarakat dapat lebih cepat atau dengan kata lain informasi lebih cepat di akses oleh masyarakat.

3. Diaharapkan dengan dengan adanya sistem informasi donor darah ini dapat menjawab kebutuhan donor darah diasaat darurat atau mendesak 


\section{DAFTAR PUSTAKA}

[1]. Basuki, 2010. Membangun web Berbasis PHP dengan Framework CodeIgniter. Yogyakarta : Lokomedia

[2]. Blanco, 2009. Codeigniter 1.7. Birmingham : Packt Publishing

[3]. Griffiths, 2010. CodeIgniter 1.7 Professional Development. Birmingham : Packt Publishing

[4]. Howe, 2010. http://foldoc.org/framework diakses pada tanggal 7 April 2014 pada pukul 20.31 wita.

[5]. Jogiyanto, Hm., MBA., Akt. Ph,D. 2005. Analisis dan Desain Sistem Informasi : Pendekatan Terstruktur Teori dan Praktek Aplikasi Bisnis.Yogyakarta : Andi.
[6]. Nailburg. E. and Maksimchuk. R., 2001, UML for Database desaign, USE ADDISONWESLEY

[7]. Soliq. 2006. Permodelan Sistem Informasi Berorientasi Objek dengan UML Yogyakarta: Graha Ilmu

[8]. Sidiq. B. 2006. Pemrograman WEB dengan PHP. Bandung : Informatika

[9]. Syarifi'i. M. 2004 Membangun Aplikasi Berbasis PHP dan MySQL. Yogakarta : Andi

[10]. Welling dan Thompson, 2003. PHP and MySQL WebDevelopment. Second Edition. Sams Publishing, Indianapolis.

[11]. Wardana, S.hut., M.si,. 2010. Menjadi Master PHP dengan Framework Codeigniter. Jakarta : Elex Media 